\title{
EPIDEMIOLOGICAL STUDY OF CHILDREN DIAPHYSEAL FEMORAL FRACTURES
}

\section{ABSTRACT}

Objective: To evaluate the personal, fracture, treatment and complication characteristics among patients with pediatric femoral shaft fractures attended at the pediatric orthopedic service of the Joana de Gusmão Children's Hospital. Methods: This was a retrospective cross-sectional study on a population consisting of patients with femoral shaft fractures, aged between birth and 14 years and 11 months, who were divided into four age groups. Information was obtained from medical records and was transferred to a survey questionnaire to present personal, fracture, treatment and complication variables. Results: The study population consisted of 96 patients. Their mean age was 6.8 years. The cases were predominantly among males, comprising closed fractures on the right side, in the middle third with a single line. Regarding fracture etiology, traffic accidents predominated overall in the sample. Most of the patients ( 74 to $77.1 \%$ ) presented femoral fractures as their only injury. Conservative treatment predominated in the group younger than six years of age, and surgical treatment in the group aged 6 to 14 years and 11 months. The complications observed until bone union were: discrepancy, infection and movement limitation. The mean time taken for consolidation was $9.6 \pm 2.4$ weeks, varying with age. Conclusion: The features of these fractures were similar to those described in the literature and the treatment used showed good results. The Joana de Gusmão Children's Hospital has used the treatment proposed in the literature for pediatric femoral shaft fractures.

Keywords - Femoral Fractures; Child; Retrospective Studies

\section{INTRODUCTION}

Pediatric diaphyseal fractures account for $1.4 \%$ to $1.7 \%$ of all fractures in the pediatric population ${ }^{(1)}$. They are more prevalent among males, with a ratio of 2.6:1. The distribution of the incidence is bimodal: the first peak between two and four years of age and the second during adolescence. There is also a seasonal distribution, with greater incidence during the summer months ${ }^{(2)}$.

Regarding etiology, the most frequent causes are traffic accidents and falls from a height ${ }^{(3)}$. Among younger children who still cannot walk, $80 \%$ of the injuries are caused by mistreatment, decreasing to $30 \%$ after they start to walk. During adolescence, around $90 \%$ of femoral fractures are caused by accidents with motor vehicles ${ }^{(2)}$. Increasing incidence of fractures caused by interpersonal violence has been

observed, most specifically among adolescents, such that occurrences of fractures caused by firearms is increasingly frequent in emergency services ${ }^{(3)}$.

The different treatment methods are dictated by the patient's age, characteristics of the trauma, conditions of the fracture and the family's social situation. Over the last decade, there has been a tendency towards surgical stabilization, particularly among children over the age of 10 years, in relation to nonsurgical treatment (traction and plaster-cast immobilization), given that the latter is associated with complications such as loss of reduction and shortening of the affected $\operatorname{limb}^{(4-6)}$. Surgical treatment (intramedullary nails and plates) has the aim of diminishing the hospital stay and social losses experienced by patients and members of their families, but this method is limited by the morbidity resulting from its complications,

1 - Resident Physician in Orthopedics and Traumatology, Joana de Gusmão Children's Hospital, Florianópolis, SC, Brazil.

2 - Orthopedist at Joana de Gusmão Children's Hospital, Florianópolis, SC, Brazil.

Work performed at Joana de Gusmão Children's Hospital, Florianópolis, SC, Brazil.

Correspondence: Rua Barão do Rio Branco 191, Centro, 89460-000 Canoinhas, SC, Brazil. E-mail: cassirh@hotmail.com

Work received for publication: May 12, 2011; accepted for publication: October 4, 2011.

The authors declare that there was no conflict of interest in conducting this work 
such as infections and growth plate lesions ${ }^{(7)}$. External fixation is indicated in cases of exposed fractures, large soft-tissue injuries, multiple trauma (especially in cases that are hemodynamically unstable), extensive comminution and burns ${ }^{(2)}$.

The present study had the aim of evaluating the characteristics of pediatric patients with fractures of the femoral diaphysis who were attended at the Pediatric Orthopedics Service of the Joana de Gusmão Children's Hospital, with regard to the following variables: age, sex, side, etiology, exposure, location, associated lesions, fracture line and treatment type.

\section{MATERIAL AND METHODS}

This was a retrospective cross-sectional study approved by the Research Ethics Committee of the Joana de Gusmão Children's Hospital.

The study population was composed of patients aged between birth and 14 years and 11 months who presented femoral diaphyseal fractures.

The inclusion criteria for this study were the following: 1) the patients should present femoral diaphyseal fractures in the proximal, middle or distal third; 2) the patient's ages should be between birth and 14 years and 11 months; 3) sufficient data had to be available in the medical files; 4) two years of follow-up was required; and 5) adequate radiographic documentation needed to be available.

The patients were divided into four age groups in accordance with the divisions proposed by Kasser and Beaty $^{(2)}$ : group I, formed by patients aged between birth and six months; group II, between six months and six years; group III, between six and 12 years; and group $\mathrm{IV}$, between 12 years and 14 years and 11 months.

The information was obtained from the medical files and was transferred to the research questionnaire. The following variables were analyzed: name, medical file number, age, sex, etiology, side, exposure, associated lesions, fracture line, treatment type, complications, time taken to achieve consolidation and clinical-radiographic assessment after consolidation.

The fracture classification was done by applying the AO fracture classification system, thus categorizing the fracture line as simple, wedge or complex ${ }^{(8)}$.

After two years of clinical-radiographic follow-up, it was considered acceptable for children up to two years of age to present angulation of up to $30^{\circ}$ in the frontal plane and $30^{\circ}$ in the sagittal plane, with up to $15 \mathrm{~mm}$ of shortening; between two and five years, $15^{\circ}$ frontal, $20^{\circ}$ sagittal and $20 \mathrm{~mm}$ shortening; between six and ten years, $10^{\circ}$ frontal, $15^{\circ}$ sagittal and $15 \mathrm{~mm}$ shortening; and between 11 years and 14 years and 11 months, $5^{\circ}$ frontal, $10^{\circ}$ sagittal and $10 \mathrm{~mm}$ shortening ${ }^{(2)}$.

The data obtained were entered into an electronic database. All the variables were distributed in the form of simple frequencies. For the numerical variables (age and time taken to achieve fracture consolidation), the central trend measurements (mean and median) were calculated. Comparisons between the proportions were given by the chi-square test. The significance level for all the analyses was 0.05 .

\section{RESULTS}

Between January 2004 and December 2009, 139 patients with femoral diaphyseal fractures were treated. Forty-three patients for whom insufficient data were available in the medical files, insufficient follow-up had taken place over the first two years after the fracture event and inadequate radiographic documentation was available were excluded. Thus, the study population was composed of 96 patients (Table 1 ).

The mean age found was 6.8 years, with a standard deviation of 4.7 years and median of 5.8 years.

Regarding the fracture etiology, traffic accidents predominated overall and in groups II, III and IV. Falls were responsible for the majority of the fractures in group I (Table 2).

In all the age groups, closed fractures predominated. There were 10 cases of open fractures: two in group III and eight in group IV. The open fractures were related to traffic accidents, firearm projectiles and falls from a height.

Fractures in the middle third of the femoral diaphysis predominated overall and in all the age groups. Group I included eight fractures in the middle third and six in the distal third. Group II presented 10 fractures in the proximal third, 20 in the middle third and four in the distal third. In group III, eight fractures were located in the proximal third, 16 in the middle third and two in the distal third; and in group IV, six were located in the proximal third, 12 in the middle third and four in the distal third.

Fractures with a simple line predominated overall and in all the age groups. In group, all the patients present a simple fracture line. In group II, 30 patients 
Table 1 - Frequency distribution of study variables.

\begin{tabular}{|c|c|c|c|}
\hline Characteristics & $\begin{array}{c}\text { Absolute } \\
\text { frequency (n) }\end{array}$ & \begin{tabular}{c|} 
Relative \\
frequency (\%)
\end{tabular} & $95 \% \mathrm{Cl}$ \\
\hline \multicolumn{4}{|l|}{ Sex } \\
\hline Female & 40 & 41.7 & $31.7-52.2$ \\
\hline Male & 56 & 58.3 & $47.8-68.3$. \\
\hline \multicolumn{4}{|l|}{ Age group } \\
\hline Group I & 14 & 14.6 & $8.2-23.3$ \\
\hline Group II & 34 & 35.4 & $25.9-45.8$ \\
\hline Group III & 26 & 27.1 & $18.5-37.1$ \\
\hline Group IV & 22 & 22.9 & $15.0-32.6$ \\
\hline \multicolumn{4}{|l|}{ Etiology } \\
\hline Falls & 28 & 29.2 & $20.3-39.3$ \\
\hline Traffic & 52 & 54.2 & $43.7-64.4$ \\
\hline Others & 16 & 16.7 & $9.8-25.6$ \\
\hline \multicolumn{4}{|l|}{ Side } \\
\hline Right & 50 & 52.1 & $41.6-62.4$ \\
\hline Left & 42 & 43.8 & $33.6-54.3$ \\
\hline Bilateral & 4 & 4.2 & $1.1-10.3$ \\
\hline \multicolumn{4}{|l|}{ Exposure } \\
\hline Closed & 86 & 89.6 & $81.7-94.9$ \\
\hline Open & 10 & 10.4 & $5.1-18.3$ \\
\hline \multicolumn{4}{|l|}{ Location } \\
\hline Proximal 1/3 & 24 & 25 & $16.7-34.9$ \\
\hline Middle $1 / 3$ & 56 & 58.3 & $47.8-68.3$ \\
\hline Distal $1 / 3$ & 16 & 16.7 & $9.8-25.6$ \\
\hline \multicolumn{4}{|l|}{ Associated lesions } \\
\hline Yes & 22 & 22.9 & $15.0-32.6$ \\
\hline No & 74 & 77.1 & $67.4-85.0$ \\
\hline \multicolumn{4}{|l|}{ Fracture line } \\
\hline Simple & 86 & 89.6 & $81.7-94.9$ \\
\hline Wedge & 4 & 4.2 & $1.1-10.3$ \\
\hline Complex & 6 & 6.3 & $2.3-13.1$ \\
\hline \multicolumn{4}{|l|}{ Treatment type } \\
\hline Conservative & 58 & 60.4 & $49.9-70.3$ \\
\hline Surgical & 38 & 39.6 & $29.7-50.1$ \\
\hline
\end{tabular}

Source: Primary data gathered from medical files at the Joana de Gusmão Children's Hospital between January 2004 and December 2009.

Table 2 - Etiology of femoral diaphyseal fractures in relation to age group.

\begin{tabular}{|c|c|c|c|c|}
\hline Group/etiology & Falls & Traffic & Others & Total \\
\hline Group I & $\begin{array}{c}8 \\
57.1 \%\end{array}$ & $\begin{array}{c}2 \\
14.3 \%\end{array}$ & $\begin{array}{c}4 \\
28.6 \%\end{array}$ & $\begin{array}{c}14 \\
100.0 \%\end{array}$ \\
\hline Group II & $\begin{array}{c}10 \\
29.4 \%\end{array}$ & $\begin{array}{c}18 \\
52.9 \%\end{array}$ & $\begin{array}{c}6 \\
17.6 \%\end{array}$ & $\begin{array}{c}34 \\
100.0 \%\end{array}$ \\
\hline Group III & $\begin{array}{c}6 \\
23.1 \%\end{array}$ & $\begin{array}{c}18 \\
69.2 \%\end{array}$ & $\begin{array}{c}2 \\
7.7 \%\end{array}$ & $\begin{array}{c}26 \\
100.0 \%\end{array}$ \\
\hline Group IV & $\begin{array}{c}4 \\
18.2 \%\end{array}$ & $\begin{array}{c}14 \\
63.6 \%\end{array}$ & $\begin{array}{c}4 \\
18.2 \%\end{array}$ & $\begin{array}{c}22 \\
100.0 \%\end{array}$ \\
\hline Total & $\begin{array}{c}28 \\
29.2 \%\end{array}$ & $\begin{array}{c}52 \\
54.2 \%\end{array}$ & $\begin{array}{c}16 \\
16.7 \%\end{array}$ & $\begin{array}{c}96 \\
100.0 \%\end{array}$ \\
\hline Chi-square & 7.05 & 12.16 & 2.99 & 13.06 \\
\hline $\mathbf{P}$ & 0.071 & 0.006 & 0.392 & 0.042 \\
\hline
\end{tabular}

Source: Primary data gathered from medical files at the Joana de Gusmão Children's Hospital between January 2004 and December 2009. presented a simple line; two, a wedge fracture; and two, a complex fracture. In group III, 22 patients presented a simple line; two, a wedge fracture; and two, a complex fracture. In group IV, 20 patients presented a simple line and two, a complex fracture.

The majority of the patients (74-77.1\%) presented a femoral fracture as a single lesion, while 22 patients $(22.9 \%)$ had one or more associated lesions. Table 3 shows the associated lesions that were most observed. It can be highlighted that one patient had more than one associated lesion.

All the patients in group I underwent conservative treatment, with immediate placement of a plaster cast. All the patients in group II underwent conservative treatment: $14(41.2 \%)$ with immediate placement of a plaster cast and $20(58.8 \%)$ with a plaster cast applied after cutaneous traction. In group III, 10 patients $(38.5 \%)$ underwent conservative treatment: seven with a plaster cast after cutaneous traction and three with plaster after transkeletal traction; and 16 patients $(61.5 \%)$ underwent surgical treatment: two with an external fixator and 14 with a flexible rod. In group IV, all the patients underwent surgical treatment: six with an external fixator, 10 with a flexible rod, two with a rigid nail and four with placement of a plate.

The mean time taken to achieve fracture consolidation in group I was 4.6 weeks, with a standard deviation of 0.8 and median of four weeks. The mean time taken to achieve fracture consolidation in group II was 10.1 weeks, with a standard deviation of 1.8 and median of 10 weeks. The mean time taken to achieve fracture consolidation in group III was 11.5 weeks, with a standard deviation of 1.4 and median of 11 weeks. The mean time taken to achieve fracture consolidation in group IV was 12 weeks, with a standard deviation of 1.4 and median of 12 weeks.

The patients in group I did not present any im-

Table 3 - Lesions associated with femoral diaphyseal fractures in relation to age group.

\begin{tabular}{c|c|c|c|c}
\hline $\begin{array}{c}\text { Group/ } \\
\text { lesion }\end{array}$ & $\begin{array}{c}\text { Other } \\
\text { fractures }\end{array}$ & $\begin{array}{c}\text { Cranioencephalic } \\
\text { trauma }\end{array}$ & Other lesions & Total \\
\hline Group I & 1 & 0 & 2 & 3 \\
\hline Group II & 1 & 0 & 2 & 3 \\
\hline Group III & 4 & 1 & 3 & 8 \\
\hline Group IV & 0 & 6 & 3 & 9 \\
\hline Total & 6 & 7 & 10 & 23 \\
\hline Chi-square & 5,82 & 17,22 & 1,25 & 13,06 \\
\hline $\mathbf{P}$ & 0,120 & 0,006 & 0,743 & 0,042 \\
\hline
\end{tabular}

Source: Primary data gathered from medical files at the Joana de Gusmão Children's Hospital between January 2004 and December 2009. 
mediate or late complication. Four patients evolved with infection: one in group III and three in group IV. Changes to knee range of motion were observed in three patients: two in group III and one in group IV. There were no angular or rotational deviations greater than the standard that had been established.

In relation to lower-limb length discrepancies measured at the time of fracture consolidation, two patients $(11.6 \%)$ in group II presented shortening of 2.5 $\mathrm{cm}$ and $3.2 \mathrm{~cm}$, respectively; four $(30.7 \%)$ in group III presented a mean discrepancy of $2.2 \pm 1.3 \mathrm{~cm}$; and three $(27.2 \%)$ in group IV presented a mean discrepancy of $1.3 \pm 0.9 \mathrm{~cm}$.

\section{DISCUSSION}

The approach used at our service for treatment pediatric femoral diaphyseal fractures was similar to what has been recommended by several authors. In most cases, it depended on the patient's age, the fracture characteristics and the family's social situation ${ }^{(6-12)}$.

In the sample analyzed, fractures in male subjects predominated, and this has also been reported by other authors $^{(5,10,11,13-15)}$. In the small sample presented by Santili et $\mathrm{al}^{(16)}$, no difference was detected in relation to gender. In a study on fractures treated conservatively, Silva et $\mathrm{al}^{(4)}$ observed that female subjects predominated.

Homogenous distribution of fractures in relation to the fractured side was also reported by Silva et $\mathrm{al}^{(4)}$, Volpon et $\mathrm{al}^{(6)}$, Linhart and Roposch ${ }^{(13)}$, Stands et $\mathrm{al}^{(14)}$ and Casas et $\mathrm{al}^{(10)}$.

The proportion of open fractures $(10.4 \%)$ was close to what was found by Cramer et $\mathrm{al}^{(5)}(8,5 \%)$, Ferguson and $\mathrm{Nicol}^{(17)}(9 \%)$, Hutchins et $\mathrm{al}^{(18)}(10 \%)$ and Linhart and $\operatorname{Roposch}^{(13)}(9.8 \%)$.

Fractures in other regions and cranioencephalic trauma are the associated lesions that have most often been described in the literature ${ }^{(5)}$. The proportion with associated lesions in the present study $(22.9 \%)$ was similar to the proportions of $26.7 \%$ reported by Buechsenschuetz et $\mathrm{al}^{(12)}$ and $22.3 \%$ of Silva et $\mathrm{al}^{(4)}$, who analyzed samples of similar age groups. Cramer et $\mathrm{al}^{(5)}$, who exclusively analyzed cases that were treated surgically, observed that $73.0 \%$ presented associated lesions. This high rate of associated lesions is, in itself, already enough to suggest that there should be greater indication of surgery.

In the literature investigated, there is no standardization regarding fracture line presentations. In 2002,
Buechsenschuetz et $\mathrm{l}^{(12)}$ found that $35.2 \%$ of the fractures were oblique, $35.2 \%$ were transverse, $16.9 \%$ were spiral and $12.6 \%$ were comminuted. Volpon et $\mathrm{al}^{(6)}$ reported that $39.8 \%$ of the fractures were transverse, $33.2 \%$ were spiral, $13.7 \%$ were short oblique, $9.0 \%$ were segmental-comminuted and $3.8 \%$ were long oblique. The data from the sample analyzed here (89.6\% with a simple line, $4.2 \%$ with wedge fractures and $6.3 \%$ with complex fractures) are closer to what was observed by Silva et $\mathrm{al}^{(4)}$, who found that $82.6 \%$ of the fractures had a simple line, $13 \%$ were wedge fractures and 4.4\% were comminuted fractures.

Casas et $\mathrm{al}^{(10)}(85,3 \%)$, Cramer et $\mathrm{al}^{(5)}(70,1 \%)$, Ferguson and Nicol ${ }^{(17)}(75 \%)$, Linhart and Roposch ${ }^{(13)}$ $(70.5 \%)$ and Staheli et $\mathrm{al}^{(11)}(73 \%)$ all reported that the fractures predominantly affected the middle third of the femur. In the present study, the fractures showed the same predominance, but with a proportion similar to what was described by Volpon et $\mathrm{l}^{(6)}(58.3 \%)$.

The literature also presents traffic accidents as the most frequent mechanism, with the exception of children under the age of three years ${ }^{(3,9,10,13,16)}$.

Traffic accidents (in which children can be victims as pedestrians, passengers in vehicles or cyclists) are the leading cause of accidental deaths in the age group from zero to 14 years in Brazil. The way in children are transported in cars may be as important as factors such as the speed of the vehicle and road conditions. The best protection for children in cars is to use safety seats, which have been regulated in Brazil through Resolution 277 of the National Traffic Council. On September 1, 2010, inspection actions started to be implemented by the traffic authorities ${ }^{(19)}$.

Several published papers have defined treatment methods according to age. Silva et $\mathrm{al}^{(4)}$, Volpon et $\mathrm{al}^{(6)}$, Casas et $\mathrm{al}^{(10)}$ and Sahin et $\mathrm{al}^{(15)}$ recommended conservative treatment as the preferred choice for femoral diaphyseal fractures in children. On the other hand, Cramer et $\mathrm{al}^{(5)}$, Linhart and Roposch ${ }^{(13)}$ and Santili et $\mathrm{al}^{(16)}$ advocated surgical treatment for children and justified this as an indication that would allow rapid recovery with a low number of complications. Sanders et $\mathrm{al}^{(9)}$ investigated the preferences of the members of the Pediatric Orthopedic Society of the United States regarding treatments for femoral fractures in children and adolescents, and observed that surgical treatment was only indicated from the age of six years onwards. In the present study, it was observed that $60.4 \%$ of the 
fractures were treated conservatively and 39.6\% surgically. Conservative treatment predominated in age groups younger than six years and surgical treatment in the age group from six years to 14 years and 11 months.

The complications encountered among the cases treated at our hospital reproduced the ones most described in the literature, i.e. loss of reduction and shortening ${ }^{(2)}$. In a sample of 85 fractures that were treated either conservatively or surgically, Stans et $\mathrm{al}^{(14)}$ identified 11 cases $(12.9 \%)$ in which the final shortening was greater than or equal to $1 \mathrm{~cm}$. Silva et $\mathrm{al}^{(4)}$ analyzed conservative treatment administered to 67 patients and observed that there were discrepancies of less than 1 $\mathrm{cm}$ in $27(40.3 \%)$ and $1-2 \mathrm{~cm}$ in $16(23.9 \%)$. At the time of consolidation, nine cases $(9.4 \%)$ of the present sample showed shortening: two (11.6\%) in group II, with shortening of $2.5 \mathrm{~cm}$ and $3.2 \mathrm{~cm}$, respectively; four $(30.7 \%)$ in group III with a mean discrepancy of $2.2 \pm 1.3 \mathrm{~cm}$; and three $(27.2 \%)$ in group IV with a mean discrepancy of $1.3 \pm 0.9 \mathrm{~cm}$.

The mean time taken to achieve consolidation among the fractures studied coincided with data in the literature. Staheli et al ${ }^{(11)}$ observed that in infants, fractures consolidated in four weeks; at the age of two years, in six weeks; between the ages of three and 10 years, from six to eight weeks; and over the age of 10 years, in eight to 12 weeks. Casas et $\mathrm{al}^{(10)}$ reported that among children aged four to ten years who were treated conservatively, the mean time taken to achieve consolidation was 9.7 weeks. Silva et $\mathrm{al}^{(4)}$ observed that the mean time taken to achieve consolidation was

\section{REFERENCES}

1. McCartney D, Hinton A, Heinrich SD. Operative stabilization of pediatric femur fractures. Orthop Clin North Am. 1994;25(4):635-50.

2. Kasser JR, Beaty JM. Fractures of the diaphysis. In: Rokwood CA, Wilkins KE. Rockwood and Wilkins' Fractures in children. Philadelphia: Lippincott-Raven; 2010. p.797-841.

3. Herbert S. Ortopedia e traumatologia: Princípios e prática. São Paulo: Artmed; 2009.

4. Silva VC, Silva LHP, Borges JLP. Fraturas diafisárias do fêmur na criança. Rev Bras Ortop 1997;32(1):6-10.

5. Cramer KE, Tornetta P 3rd, Spero CR, Alter S, Miraliakbar H, Teefey J. Ender rod fixation of femoral shaft fractures in children. Clin Orthop Relat Res. 2000;(376):119-23.

6. Volpon JB, Porto Filho MR, Moretto M. Tratamento conservador das fraturas diafisárias do fêmur da criança. Rev Bras Ortop. 1997;32(1):11-6.

7. Kocher MS, Sink EL, Blasier RD, Luhmann SJ, Mehlman CT, Sher DM, et al. Tratamento das fraturas femorais diafisárias pediátricas. J Acad Orthop Surg AAOS. 2010;8:55-63. (Tradução).

8. Wolinsky P, Stephen DJ. Femur, diáfise. In: Rüedi TP, Buckley RE, Moran CG. Princípios $\mathrm{AO}$ do tratamento de fraturas. Tradução Jacques Vissoky. 2a. ed. Porto Alegre: Artmed, 2009. p. 849-67.

9. Sanders JO, Browne RH, Mooney JF, Raney EM, Horn BD, Anderson DJ, et al. Treatment of femoral fractures in children by pediatric orthopedists: results of a 1998 survey. J Pediatr Orthop. 2001;21(4):436-41.

10. Casas J, Gonzalez-Moran G, Albinana J. Femoral fractures in children from 4 year to 10 year: conservative treatment. J Pediatr Orthop B. 2001;10(1):56-62. eight weeks among children aged three to 13 years.

The great number of losses due to insufficient data in the medical files and insufficient follow-up was a limiting factor in this study.

It is important to emphasize to physicians that filling out the forms for the medical files is important. Families need to be told that follow-up throughout the course of treatment is important.

Raising the public's awareness about preventive measures against traffic accidents and better inspection are needed in order to diminish the incidence of pediatric femoral diaphyseal fractures.

\section{CONCLUSION}

The patients attended at the Orthopedics and Traumatology Service of the Joana de Gusmão Children's Hospital with a diagnosis of femoral diaphyseal fracture were mainly males. The age group most affected was between six months and six years. Traffic accidents predominated as the etiology.

Closed femoral diaphyseal fractures predominated. The most common location was the middle third and the fracture line type most often encountered was the simple type.

The treatment most used was conservative, in the age group under six years, and surgical in the age group from six years to 14 years and 11 months. The Joana de Gusmão Children's Hospital used the treatment proposed in the literature for pediatric femoral diaphyseal fractures.

11. Staheli LT. Fraturas da diáfise do fêmur. In: Rockwood CA Jr, Wilkins KE, King RE. Fraturas em crianças. Tradução de Vilma R. de Souza Varga et al. 3a. ed. São Paulo:Manole; 1993. p. 1095-133.

12. Buechsenschuetz KE, Mehlman CT, Shaw KJ, Crawford AH, Immerman EB. Femoral shaft fractures in children: traction and casting versus elastic stable intramedullary nailing. J Trauma. 2002; 53:914-20.

13. Linhart WE, Roposch A. Elastic stable intramedullary nailing for unstable femoral fractures in children: preliminary results of a new method. $\mathrm{J}$ Trauma. 1999;47(2):372-8.

14. Stans AA, Morrissy RT, Renwick SE. Femoral shaft fracture treatment in patients age 6 to 16 years. J Pediatr Orthop. 1999;19(2):222-8.

15. Sahin V, Baktir A, Türk CY, Karakaş ES, Aktaş S. Femoral shaft fractures in children treated by closed reduction and early spica cast with incorporated supracondylar Kirschner wires: a long-term follow-up results. Injury. 1999;30(2):121-8.

16. Santili C, Akkari M, Waisberg G, Camargo AA, Nogueira FP, Prado JCL. Haste flexível de titânio na fratura de fêmur na criança. Rev Bras Ortop 2002;37(5):176-81.

17. Ferguson J, Nicol RO. Early spica treatment of pediatric femoral shaft fractures. J Pediatr Orthop. 2000;20(2):189-92.

18. Hutchins CM, Sponseller PD, Sturm P, Mosquero R. Open femur fractures in children: treatment, complications, and results. J Pediatr Orthop. 2000;20(2):183-8.

19. BRASIL. Criança segura. Disponível em: http://www.criancasegura.org.br. Acesso em 3 janeiro de 2011. 